\title{
Risk Assessment of Food Coloring Agents on DNA Damage Using RAPD Markers
}

\author{
Hala M. Abdelmigid*,\# \\ Botany Department, Faculty of Science, Mansoura University, Egypt
}

\begin{abstract}
In this study, faba bean (Vicia faba) seedlings were used as bioindicator to determine genotoxic effect of synthetic dyes currently used as food color additives in many countries. Novel short-term assays are required to substantiate the battery of assessment methods for evaluating the genotoxicity of candidate substances. Therefore, an attempt has been made to evaluate randomly amplified polymorphic DNA (RAPD) analysis for its potential to establish genotoxic effect of colored food. For the preliminary assessment, this study compared the effects occurring at molecular levels in Vicia faba exposed to colored food at concentrations in the range of $0.2 \%$ to $18.2 \%$. The qualitative modifications arising in random amplified polymorphic DNA (RAPD) profiles as a measure of DNA effects were compared with control. Results suggested that treatments of the above test food samples reflect changes in RAPD profiles. Changes in RAPD patterns included variation in band intensity; loss of normal bands and appearance of new bands compared with control. These results indicated that DNA polymorphisms detected by RAPD analysis could be used as an investigation tool for environmental toxicology and as a useful biomarker assay for the detection of genotoxic effects of food dyes. In conclusion, the measurement of parameters at molecular levels is valuable for investigating the specific effects of agents interacting with DNA. Ultimately, this methodology may allow the ecotoxicological examination of the link between molecular alterations and measurable adverse effects at higher levels of biological organization.
\end{abstract}

Keywords: Food colors, RAPD, DNA effects, Vicia faba.

\section{INTRODUCTION}

Color additives are defined as dyes, pigments or substances that can impart color when added or applied to food, drugs, or cosmetics and to certain medical devices such as contact lenses [1]. Color additives are used in food for many reasons, including to offset color loss due to storage or processing of foods, to correct natural variations in food color, and finally to enhance the appearance of certain good to meet consumer demands and expectations; e.g. natural carotene (E 160a), annatto (E 160b) are added to butter for this last reason. the capital ' $\mathrm{E}$ ' in front of the number means that additive has been passed for food use throughout the European Community. Over the years, improvements have been made in increasing the efficiency and ensuring the safety of all additives. Today, food and color additives are more strictly regulated than at any other time in history. hence, any food additive requires FDA approval for use prior to its inclusion in food. It also requires the manufacturer to prove an additives safety for the ways it will be used. In 1958, FDA or the U.S. Department of Agriculture (USDA) had determined a category of substances that are Generally Recognized as Safe or, GRAS, whose use is generally recognized by experts as safe based on their extensive history of use in food, or based on published scientific evidence. Since 1958, FDA and USDA have continued to monitor all GRAS substances in light of new scientific information if new evidence

*Address correspondence to this author at the Botany Department, Faculty of Science, Mansoura University, Egypt;

E-mail: halaabdelmigid@yahoo.com

"Present address: King Khaled University, Abha, KSA, P.O. 3340, and kingdom Saudia Arabia suggests that a GRAS may be unsafe, federal authorities can prohibit its use or require further studies to determine its safety [2].

A number of reviews concerning the toxicology of natural and synthetic dyes, specially those used in food, have appeared since the dyestuffs became potential suspects for causing cancer [3, 4]. A large number of natural or synthetic dyes have been removed from both national and international lists of permitted food colors because of their mutagenic or carcinogenic activity. To the majority of the food additive JECFA/FAO has assigned "Admissible Daily Intake Dose" ADI, which are often temporary and emphasized the need for further genotoxic evaluation, since a number of them are reported to be genotoxic below the ADI dose. Some food colors and their side effects have been investigated in animal studies [4] and it has been found that their mutagenicity varies widely, depending on the dose consumed. Most substances which have been found to be mutagenic, also seem to have a carcinogenic action for example, carmoisine (E122), amaranth (E123), Sunset Yellow (E110), Tartrazine (E102) and Allura red (E129). Furthermore, some of them have been found to cause mutations in some bacteria, implying that they may also act as mutagenic and/or carcinogenic agents in humans $[1,5]$ Hence, they may affect genome integrity due to mutations in germinal and/or somatic cells, leading to an increase in the incidence of different types of tumours [6]

The OCDE Guidelines [7] list a series of widely used techniques, both in vivo and in vitro, for use in risk assessment procedures associated with genotoxins for humans. However, the application of these traditional techniques to the detection in DNA of both macro- and micro-damage (sis- 
ter chromatid exchange, chromosomal aberrations, etc.) are particularly tedious when applied to higher organisms, due to the high number of chromosomes and the long cell cycle found in cells. Literature survey on the food colors revealed that majority of the toxicity tests performed were antiquated. Recently, the tremendous progress made in molecular biology and genetics resulted in the development of modern diagnostic technologies. These technologies include several extremely reliable assays such as DNA fingerprinting and gene amplification by PCR for screening different types of biotic and abiotic environmental agents for their mutagenic and potentially carcinogenic activity. These new diagnostic assays also offer new possibilities for detecting DNA damage, and characterization of the genotoxic effects of chemicals commonly used in the food industry [8]. A number of laboratory methods has been widely studied to investigate the effect of mutagens on living organisms. However, molecular markers allow a direct comparison of the effects of genotoxins at the DNA level. The explorations of random amplified polymorphic DNA (RAPD) as genetic markers have improved the detection of DNA alterations after the influence of many genotoxic agents [9]. On the other hand, several international research programs which is among the many research programs and strategies for monitoring and testing potential mutagens (e.g., The International Program of
Chemical Safety and the Program of the Committee on the Mutagenicity of Chemicals in food, consumer products and the environment) recommend as a preliminary study, Vicia as a rapid economical and reproducible short-term test system [10].

In the context of the information provided above, the objectives of this study have been, to investigate the possibility of mutation changes in Vicia faba after the influence of colored food using RAPD method, to determine whether the RAPD assay could detect food colors-induced DNA effects in plant DNA, and to assess how these endpoints (i.e. changes in RAPD profile) compare in terms of detection of toxicity. The main purpose of this study is to evaluate the potential genotoxic effects of colored food samples, via the RAPD assay, using a plant-based test. Thus, a preliminary investigation was undertaken to assess the risk of using the colored food on DNA damage.

\section{MATERIALS AND METHODS}

\section{Tested Food Samples}

A total of 10 samples from four different food categories were employed in the present study. Food groups included were: fruit drinks, jelly crystals, extruded snacks and confectionery. All samples were purchased from the market and

Table 1. Samples of Food Products, their Categories, the Colors Included and Concentrations Used in this Study

\begin{tabular}{|c|c|c|c|c|}
\hline FOOD CATEGORY & PRODUCT & COLOR NAME & E NUMBER & CONC. \\
\hline Jelly crystals & Gelatin dessert (Gl) & Tartazine & E102 & $18.2 \%$ \\
\hline \multirow[t]{2}{*}{ Fruit drink } & Tang (Tg) & Sunset yellow & E110 & $12 \%$ \\
\hline & Vimto (Vm) & Red Allura & E129 & $0.2 \%$ \\
\hline \multirow{12}{*}{ confectionery } & \multirow{4}{*}{ Gummy jelly candies (Rg) } & Sunset yellow & E110 & \multirow{4}{*}{$5 \%$} \\
\hline & & Allura Red & E129 & \\
\hline & & Brilliant Blue & E133 & \\
\hline & & Titanium dioxide & E171 & \\
\hline & Fruit pastilles(Tf) & Titanium dioxide & E171 & \\
\hline & \multirow{3}{*}{ Custard powder $(\mathrm{Bu})$} & Tartazine & E102 & \multirow[t]{3}{*}{$5 \%$} \\
\hline & & Sunset yellow & E110 & \\
\hline & & Red Allura & E129 & \\
\hline & \multirow[t]{4}{*}{ Fruit candies skittles (Sk) } & Tartazine & E102 & \multirow[t]{4}{*}{$6 \%$} \\
\hline & & Sunset yellow & E110 & \\
\hline & & Allura Red & E129 & \\
\hline & & Brilliant Blue & E133 & \\
\hline
\end{tabular}


used directly for analysis. Samples were prepared for consumption in accordance with instructions on food packaging. Food products and color ingredients are included in Table $\mathbf{1 .}$

\section{Treatments}

Seeds of Vicia faba were germinated under a temperature range of $5 \pm 2{ }^{\circ} \mathrm{C}$. Seedlings of 3 days old were treated for 3 hours, with the prepared concentrations of food samples

\section{Extraction of Genomic DNA}

Seedlings were used for isolation of genomic DNA. Isolation was done following the Cetyl Trimethyl Ammonium Bromide (CTAB) method of [11]. 0.5gm of fresh samples was ground to powder in liquid nitrogen with a prechilled pestle and mortar, suspended in $5 \mathrm{ml}$ preheated CTAB buffer, and incubated at $65^{\circ} \mathrm{C}$ for 1 hour with occasional shaking. The homogenate was then mixed with $1 / 3$ volume of chloroform, mixed gently, centrifuged and the upper phase was transferred to a new sterilized tube.

Extraction was repeated with an equal volume of chloroform. The aqueous layer was transferred to a new tube, 2/3 volume of isopropanol was added and nucleic acids were either spooled using a Pasteur pipette or sedimentated by centrifugation. The pellet was washed carefully twice with $70 \%$ ethanol, dried at room temperature and resuspended in $0.5 \mathrm{ml}$ TE buffer. The enzyme, RNAse A $(20 \mu \mathrm{g})$ was added to the resuspended mixture to digest any contaminating RNA and the tube was incubated at $37{ }^{\circ} \mathrm{C}$ for $30 \mathrm{~min}$. To remove the enzyme and other contaminating protein, phenol/ chloroform extraction was performed.

\section{Quantification of DNA}

The quantity of DNA present in each sample was determined by reading the absorbance at $260 \mathrm{~nm}$. Kontron spectrophotometer was used to determine the DNA yield and purity. After quantification, all the samples were diluted to $50 \mathrm{ng} / \mathrm{ml}$ and used for PCR reactions.

\section{Random Amplified Polymorphic DNA (RAPD) Analysis}

DNA from samples were used for RAPD analysis following the method recommended by [12] The cocktail for the amplification was prepared as follows in 25 ul PCR tubes: genomic DNA $50 \mathrm{ng} / \mathrm{ml}, 25 \mathrm{pmol} \mathrm{dNTPs}$, and $25 \mathrm{pmol}$ of random primer, 0.8 units of Taq DNA polymerase. A set of five 10-mer primers (Operon technologies Inc., Alameda, California ) randomly selected were used in RAPD analysis (Table 2). The reaction mixture was given a short spin for thoroughly mixing of the cocktail components. Then the

Table 2. List of Random Primers Used for RAPD Analysis

\begin{tabular}{|c|c|c|c|}
\hline No & Primer & Sequence ( $5^{\prime}$ to $\left.3^{\prime}\right)$ & $\begin{array}{c}\text { Annealing } \\
\text { Tm }{ }^{\circ} \mathrm{C} / \text { Sec }\end{array}$ \\
\hline 1. & A1 & TGGCGACCTG & \multirow{5}{*}{$36^{\circ} \mathrm{C}$} \\
\hline 2. & A 2 & GAGGCGTCGC & \\
\hline 3. & B1 & CCCTACCGAC & \\
\hline 4. & B2 & TCGTTCCGC & \\
\hline 5. & B3 & САССТТТССС & \\
\hline
\end{tabular}

PCR tubes were loaded on to a thermal cycler (PTC-100 MJ Research TM Inc., USA).

The PCR programme included an initial denaturation step at $94^{\circ} \mathrm{C}$ for 2 mins followed by 45 cycles with $94^{\circ} \mathrm{C}$ for 1 min for DNA denaturation, annealing as mentioned with each primer, extension at $72^{\circ} \mathrm{C}$ for 30 seconds and final extension at $72{ }^{\circ} \mathrm{C}$ for 10 minutes were carried out (Table 3 ).

Table 3. The RAPD-PCR Reaction Parameter

\begin{tabular}{|c|c|c|}
\hline Profile & PCR Program & No. of Cycles \\
\hline \hline 1 & $94^{\circ} \mathrm{C} 2 \mathrm{~min}$ & Initial denaturation \\
\hline 2 & $94^{\circ} \mathrm{C} 1 \mathrm{~min}$ & \multirow{2}{*}{45 cycles } \\
\hline 3 & $36^{\circ} \mathrm{C} 1 \mathrm{~min}$ & \multirow{2}{*}{ Final extension } \\
\hline 4 & $72^{\circ} \mathrm{C} 30 \mathrm{sec}$ & hold \\
\hline 5 & $72^{\circ} \mathrm{C} 10 \mathrm{~min}$ & \\
\hline 6 & $4{ }^{\circ} \mathrm{C}$ & \\
\hline
\end{tabular}

\section{Gel Electrophoresis}

The amplification products were analyzed by electrophoresis according to [13]. Along with the PCR amplified products, 100 bp DNA ladders (Promega) as standard marker were subjected to electrophoresis in $2 \%$ agarose gel in TAE buffer and stained with ethidium bromide. Molecular size of the marker was 1000, 900, 800, 700, 600, 500, 400, 300, 200 and $100 \mathrm{bp}$. The amplified pattern was visualized on a UV transilluminator and photographed. Polymorphism was evidenced as the presence and / or absence of DNA fragments between the samples.

\section{RESULTS}

The RAPD assay carried out with 50 ng of control genomic DNA and yielded 3-7 bands (Fig. 1a-e). In total, 5 oligonucleotide primers were used in the analysis and were able to produce reproducible RAPD bands with template DNA from Vicia seedlings. The presence of changes in the RAPD profiles obtained from the treated and control Vicia cells depended on the primer used. With respect to treated seedlings, the number of bands for each primer varied ranging from three for primer B2 (Fig. 1d) to eight for primer B3 (Fig. 1e). DNA profiles generated by the five primers revealed differences between control and treated cells, with visible changes in the number and size of amplified DNA fragments, and both increases and decreases of DNA band intensities. Arrows on the right of each gel (Fig. 1) show some of the obvious modifications. Although some changes in RAPD profiles arose at $\mathrm{Ms}, \mathrm{Pu}, \mathrm{Tf}, \mathrm{Rg}, \mathrm{Bu}$ treatments e.g. bands B2-1; A2-5 (changes in band intensity), B2-3 (appearance of new bands), most of the modifications occurred in patterns of seedlings treated with $\mathrm{Sk}, \mathrm{Ch}, \mathrm{Tg}, \mathrm{Gl}$ and $\mathrm{Vm}$. Table 4 shows that extra bands generally appeared for some or all of the DNA treated with those test samples (e.g. bands A1-1, B3-6, B1-7).

In addition, disappearance of bands was the major event arising in the patterns generated by the seedlings treated with some test samples such as Sk (e.g., bands A1-2,A1-3,A2-1). In treatments such as $\mathrm{Ch}$ sample, every type of other modifi- 
(a)

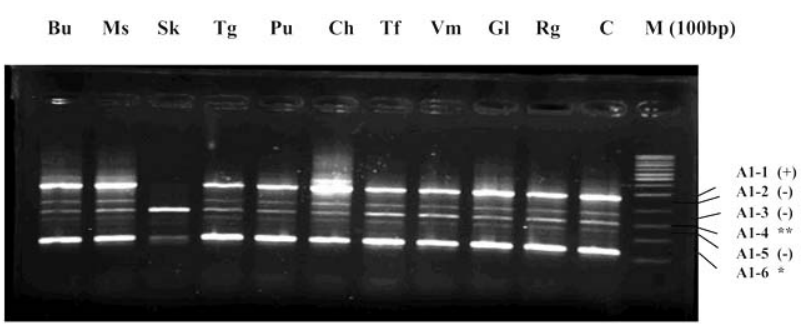

A1 primer (b)
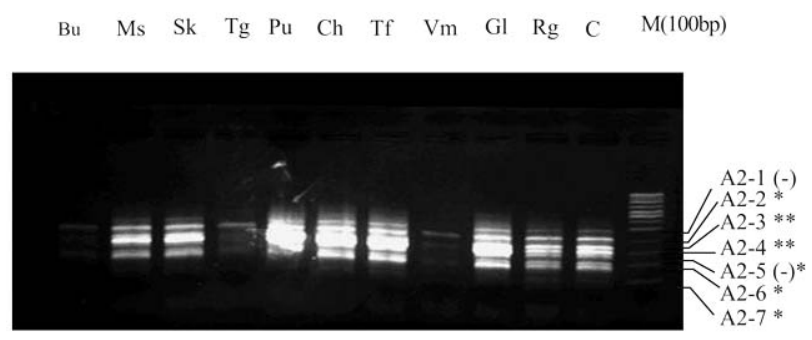

A2 primer (c)

$$
\begin{array}{llllllllllll}
\text { Bu } & \text { Ms } & \text { Sk } & \text { Tg } & \text { Pu } & \text { Ch } & \text { Tf } & \text { Vm } & \text { Gl } & \text { Rg } & \text { C } & \text { M (100bp) }
\end{array}
$$

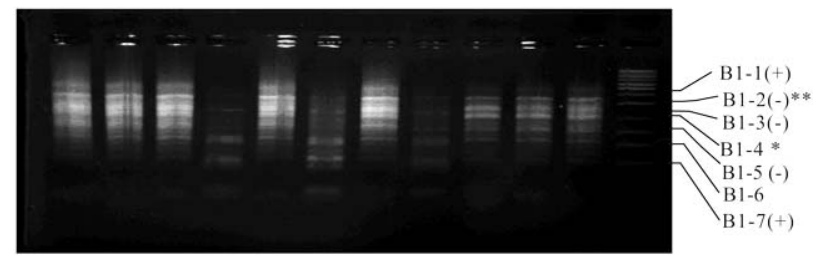

B1 primer (d)

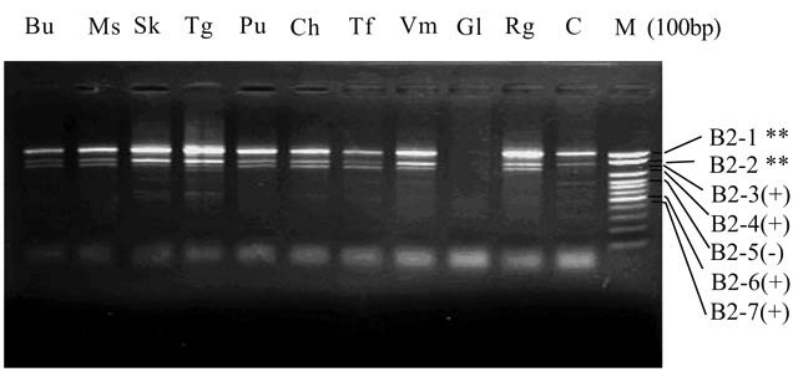

B2 primer

(e)

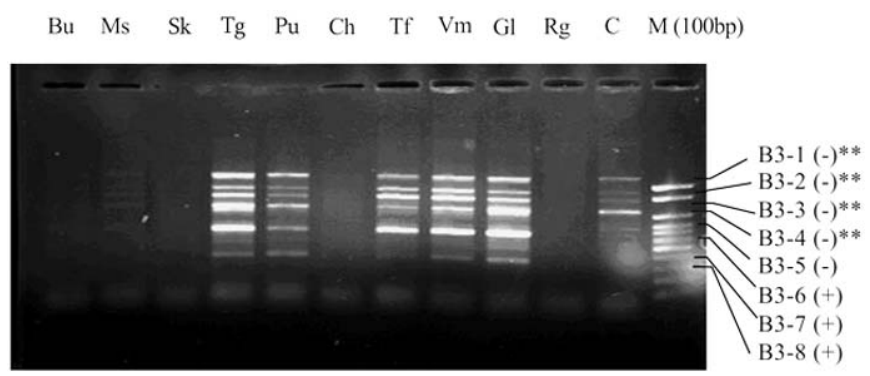

B3 primer

Fig. (1). RAPD profiles of Vicia faba seedlings treated with colored food samples, M, DNA molecular size marker (100 bp DNA ladder). RAPD profiles were generated using 10-mer primer A1 (a), A2 (b), B1 (c), B2 (d) and B3 (e). Selected changes are indicated by arrows in comparison to control patterns. *decrease in band intensities; ** increase in band intensities + , appearance of a new band; -, disappearance of a band.

cation was well represented in the patterns produced by Vicia seedlings. It is clear from Table $\mathbf{4}$ and Fig. (1) that band intensity followed two different tendencies. Intensity of most of the bands increased whereas other bands exhibited decreased intensity, compared to control. For instance, the intensity of band A2-4 was generally brighter at Tf, Gl, $\mathrm{Ch}, \mathrm{Pu}$, Sk whereas the intensity of band A2-6 progressively decreased at $\mathrm{Bu}, \mathrm{Tg}, \mathrm{Vm}$ treatments.

\section{DISCUSSION}

It is apparent that the main changes observed in the RAPD profiles have resulted both in the appearance or disappearance of different bands with variations of their inten- sity as well. These effects may be correlated with structural rearrangements in DNA caused by different types of DNA damages [14]. The variation in band intensity and disappearance of some bands may correlate with level of photoproducts in DNA templates after treatment, which can reduce the number of binding sites for Taq polymerase. Appearance of new bands can be explained as the result of DNA structural changes (breaks, transpositions, deletions, etc.) [9]. This variation among different samples may be due to their different chemical compositions of food colors and at the same time their manufacturing processes.

Different studies reported that food colors might cause health hazards affecting kidneys and causing allergies, gas- 
Table 4. Different Types of Profile Change Induced by Treatments of Test Food Samples in Vicia Cells

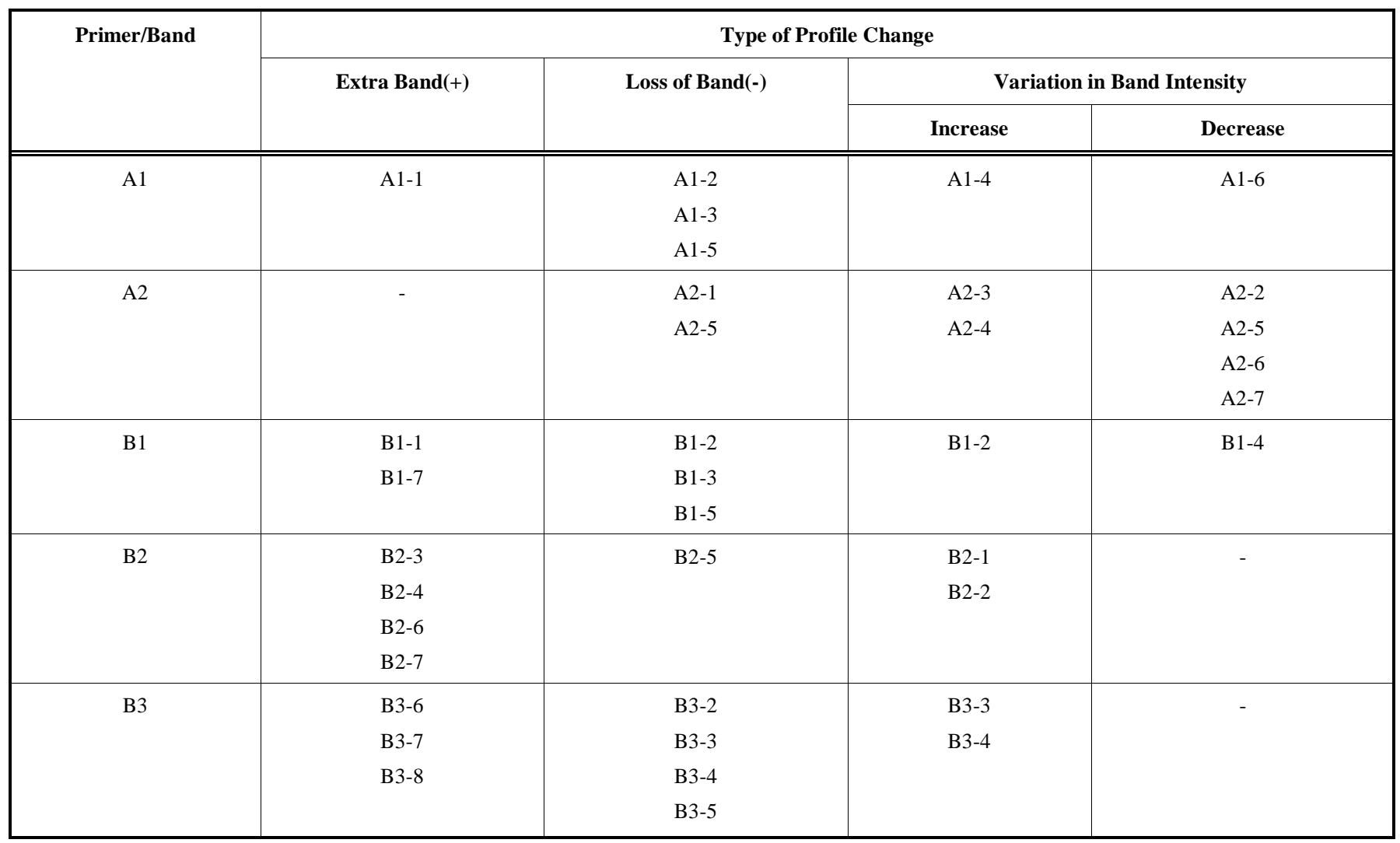

trointestinal and cancer problems $[4,15]$. In the same way, cell populations exposed in vitro to genotoxins suffer DNA alterations in a certain number of cells, which are reflected as variations in the fingerprint obtained for the control population. These are defined as band losses and/or gains as well as alterations in the intensity of amplification of some of them. Such alterations in vivo are considered mutations that are produced by changes to, deletions of or insertions into the pair bases [9, 16]. These different types of DNA damages must be detected by changes in RAPD profiles. Food colors have been reported as a well-known mutagenic and clastogenic agent. Previous studies suggested food color as one of the best known chemical mutates as it reacts with the biomolecules including DNA and damage their structure and biological activity [3, 4, 15]. Therefore, genetic alterations occur on the DNA molecules. The result obtained in this work was in accordance with previous studies on the same plant-test [1].

Regarding the constituents of the test food products under study, it is shown that all of them contain many food additives particularly artificial food colors (Table 1). Some of them were recorded as mutagens by other studies. For example, carmoisine (E122), Tartrazine (E102) and Allura red (E129) have been found in animal studies to have either mutagenic or carcinogenic action [4, 15]. Others were also banned in many countries [3]. A comprehensive review of the genotoxicity of food, drug, and cosmetic dyes was published by $[19,20]$. With respect to food color toxicity, it is apparent that for many dyes, considerable inconsistency exists not only between bioassay and various short term results, but also among the various short term tests. It has been re- ported that lethal effects on both plant and human cells occurred after cell exposure to food colors [1]. In another study, [3] the most widely tested dyes, amaranth and tartrazine, have been shown not to be carcinogenic or genotoxic in most short-term tests, including the Ames assay. This great variability among different studies makes direct comparisons difficult. The result of this preliminary study which was undertaken to study the induction of DNA damage in Vicia cells by food colors revealed the potential mutagenicity of those colors. Overall, there was no observed beneficial effect in Vicia cells treated with colored food samples. Thus, despite the discrepancies found between the opinions of different studies concerning the genotoxicity of food dyes, the present study shows that more extensive assessment of these dyes is warranted to study the DNA damaging potential of them on living cells and consequently on human health.

One objective of this study was to evaluate the potential of the RAPD method to detect DNA effects of food colors in Vicia faba. Recently, the RAPD technique has been successfully used to detect DNA effects induced by benzo (a) pyrene [21], mitomycin C [22], ultraviolet radiation [23], under in vitro and in vivo conditions. RAPD profiles detect alterations to genomic DNA through the use of arbitrarily primed PCR reactions. These effects include changes in oligonucleotide priming sites and variations in the activity of the Taq DNA polymerase. In the present study, variation in band intensity, disappearance of bands, and appearance of new PCR products occurred in profiles generated from the treated seedlings. Food colors -induced DNA damage, may significantly interfere with the PCR events. It has been reported that such structural changes are likely to have a significant effect on 
the kinetics of PCR events [24]. New PCR products can be amplified because some sites become accessible to the primers after structural change or because the same mutations have occurred in the genome. Amongst the new bands observed in the exposed cells, bands B2-3 and B3-7, were detected for most of the treatments. This leads one to think that these bands are the result of a food color-directed action on specific points on the genomic DNA. This is in accordance with the study of $[17,18]$.

A loss of an amplicon can only be the outcome if the same structural changes occur in $75-90 \%$ of the cells or if the same mutations arise in the same percentage of cells [25]. However, it is very unlikely that mutations occur in a large portion of cells, because most of the DNA damage (which can lead to mutations during DNA replication) will be efficiently repaired. DNA lesions such as bulky adducts are expected to have detrimental effects on RAPD profiles. Not only can they induce structural changes, but they can also reduce the polymerization of the DNA and/or block the Taq DNA polymerase [26] which will result in a decrease in band intensity, or alternatively, in a disappearance of amplified products in the case of extensive DNA damage [25].

The preliminary results in this investigation indicate that DNA damage allow a visible change in the RAPD profile. This led to suggest that treatments of the test food samples may lead to the production of mutations with changes in base pairs $[27,28]$ which can give the primer the opportunity to find new hybridization sites and obtain products of similar molecular weight but with different sequences [29]. The qualitative analyses showed a new high molecular weight band (B2-3) and the frequency of appearance of some bands decreases (e.g., B3-1; B3-2; B3-3; B3-4), so that new and possibly unstable hybridizations may be suspected. A decrease in the amplification of high molecular weight bands could be produced as a result of the clastogenic action of the coloring agents in the studied samples. The provided data proved the RAPD technique as a promising tool in the in vitro detection of alterations in DNA produced by genotoxic agents, allowing us to see the mechanisms of action of the agent in greater detail. Moreover, the practically unlimited number of informative primers provides a good overall coverage of genomic DNA [30] so that the choice of a set of primers with different sequences will allow increased sensitivity of the assay in the detection of low frequency mutation events. The main advantages of the RAPD method lie in its rapidity, applicability to any organism (since no information on the nucleotide sequence, cell cycle, or chromosome complement is required), and sensitivity to detect a wide range of DNA damage and mutations [18, 31, 32]. However, RAPD is a qualitative method and the nature and amount of DNA effects can only be speculated. Thus, in the context of the evaluation of pollutant-induced DNA effects, a powerful approach would be to perform the RAPD method to obtain qualitative data that would give an overview of the DNA effects, and then to use more specific methods such as DNA strand break measurements (comet assay), or cytogenetic assays to generate quantitative data.

\section{CONCLUSION}

In conclusion, DNA effects are sensitive markers to detect food colors toxicity in higher organisms including hu- mans. Thus, the RAPD assay to detect DNA effects in conjunction with other biomarkers from higher levels of biological organization would prove a powerful ecotoxicological tool. It has to be emphasized that this diagnosis has been made based on analyses utilizing modern and sensitive assays (RAPD assay) performed on the root tip meristem cells of Vicia faba in vivo. The observations indicate that food colors, either natural or synthetic can induce wide range of adverse reactions in sensitive individuals and these colors may be considered as carcinogenic in nature. Therefore a systematic approach to evaluate the frequency of the occurrence of toxic and non-permitted colors for the estimation should be carried out within countries. At the same time we must also enforce certain rules or laws to prevent effects of food color.

\section{REFERENCES}

[1] Macioszek VK, Kononowicz AK. The evaluation of the genotoxicity of two commonly used food colors; Quinoline Yellow (E104) and Brilliant Black BN (E151). Cell Mol Biol Lett 2004; 9: 107-22.

[2] Kroes R, Kozianowski G. Threshold of toxicological concern in food safety assessment. Toxicol Lett 2002; 127(1-3): 43-6.

[3] Das A, Mukherjee A. Genotoxicity testing of the food colours amaranth and tartrazine. Int J Hum Genet 2004; 4(4): 277-80.

[4] Tsuda S, Murakami M, Matsusaka N, Kano K, Taniguchi K, Sasaki YF. DNA damage induced by red food dyes orally administered to pregnant and male mice. Toxicol Sci 2001; 61: 92-99.

[5] Zeiger E. Mutagenicity of chemicals added to foods. Mutat Res 1993; 290: 53-61.

[6] Le Blanc GA, Bain L. Chronic toxicity of environmental contaminants: sentinels and biomarkers. Environ Health Perspect 1997; 105: $65-80$.

[7] OECD. Mammalian erythrocyte micronucleus test. no. 474. Addenum to OCDE Guidelines for Testing Chemicals. France: OCDE 1998.

[8] Sasaki YF, Kawaguchi S, Kamaya A, Ohshita M, Kabasawa K, Iwama K. The comet assay with 8 mouse organs: results with 39 currently used food additives. Mutat Res 2002; 519: 103-9.

[9] Atienzar FA, Cheung VV, Jha AN, Depledge MH. Fitness parameters and dna effects are sensitive indicators of copper-induced toxicity in Daphnia magna. Toxicol Sci 2001; 59: 241-50

[10] Sandhu SS, Serres FJ, Goplan HN, et al. Environmental monitoring for genotoxicity with plant systems. Results and recommendations. Mutat Res 1994; 310: 257-63.

[11] Doyle JJ, Doyle JL. Isolation of plant DNA from fresh tissue. Focus 1990; 12: 13-15.

[12] Williams J, Kubelik AR, Livak JK, Rafalski JA, Tingey SV. DNA polymorphism amplified by arbitrary primers are useful as genetic markers. Nucleic Acids Res 1990; 18: 6535.

[13] Sambrook J, Fritsch EF, Maniatis T. Molecular cloning: a laboratory manual. Cold Spring Harbor: New York 1989.

[14] Becerril C, Ferrero M, Castaño A. Detection by RAPD of genetic alterations in vitro: amplification and conservation conditions of DNA extracts. Toxicol Mech Methods 2002; 12(2): 155-67.

[15] Tuormaa E. The adverse effects of food Additives on health (Booklet). J Mol Med 1994; 9 (4): 225- 243.

[16] Danylchenko O, Sorochinsky B. Use of RAPD assay for the detection of mutation changes in plant DNA induced by UV-B and $\gamma$ rays. BMC Plant Biol 2005; 5(1): S9.

[17] Selvi BS, Ponnuswami V, Sumathi T. Identification of DNA polymorphism induced by gamma ray irradiation in amla (Emblica Officinalis Gaertn.) Grafts of V M and V M Generation. J Appl Sci Res 2007; 3(12): 1933-5.

[18] Liu W, Yang YS, Li PJ, Zhou QX, Xie LJ, Han YP. Risk assessment of cadmium-contaminated soil on plant DNA damage using RAPD and physiological indices. Hazard Mater 2008;18.

[19] Combes RD, Haveland-Smith RB, A review of the genotoxicity of food, drug and cosmetic colours and other azo, triphenylmethane and xanthene dyes. Mutat Res 1982; 98: 101-248.

[20] Giri AK. Food dyes in India: mutagenic and clastogenic potentialsA review. Proc Indian Natn Sci Acad 1991; B57: 183-98.

[21] Atienzar FA, Conradi M, Evenden AJ, Jha AN, Depledge and MH. Qualitative assessment of genotoxicity using random amplified po- 
lymorphic DNA: comparison of genomic template stability with key fitness parameters in Daphnia magna exposed to benzo[a]pyrene. Environ Toxicol Chem 1999; 18: 2275-82.

[22] Becerril C, Ferrero M, Sanz F, Castano A. Detection of mitomycin $\mathrm{C}$-induced genetic damage in fish cells by use of RAPD. Mutagenesis 1999; 14: 449-56.

[23] Atienzar FA, Cordi B, Donkin ME, Evenden AJ, Jha A N, Depledge MH. Comparison of ultraviolet-induced genotoxicity detected by random amplified polymorphic DNA with chlorophyll fluorescence and growth in a marine macroalgae, Palmaria palmata. Aquat Toxicol 2000; 50: 1-12.

[24] De Wolfe H, Blust R, Backeljau T. The use of RAPD in ecotoxicology. Mutat Res 2004; 566(3): 249-62.

[25] Atienzar FA. Development of the random amplified polymorphic DNA (RAPD) technique to measure the effects of genotoxins in aquatic organisms. Ph.D. Thesis, (DXN034438), UK: University of Plymouth 2000.

[26] Nelson JR, Lawrence CW, Hinkle DC. Thymine-thymine dimer bypass by yeast DNA polymerase. Science 1996; 272: 1646-49.
[27] Srikanth NS, Mudipalli A, Maccubbin AE, Gurtoo HL. Mutations in a shuttle vector exposed to activated mitomycin C. Mol Carcinog 1994; 10: 23-9.

[28] Maccubbin AE, Mudipalli A, Nadadur SS, Ersing N, Gurtoo HL. Mutations induced in a shuttle vector plasmid exposed to monofunctionally activated mitomycin C. Environ Mol Mutagen 1997; 29: 143-51.

[29] Riesenberg LK. Homology among RAPD fragments in interspecific comparisons. Mol Ecol 1996; 5: 99-105.

[30] Ramser J, Lopez-Peralta C, Wetzel R, Weising K, Kahl G. Genomic variation and relationships in aerial yam (Dioscores bulbifera L.) detected by ramdon amplified polymorphic DNA. Genome 1996; 39: 1725 .

[31] Noel S, Rath SK. Randomly amplified polymorphic DNA as a tool for genotoxicity: an assessment. Toxicol Ind Health 2006; 22(6): 267-75.

[32] Lee YC, Yang VC, Wang TS. Use of RAPD to detect sodium arsenite-induced DNA damage in human lymphoblastoid cells. Toxicology 2007; 239: 108-15.

(C) Hala M. Abdelmigid; Licensee Bentham Open.

This is an open access article licensed under the terms of the Creative Commons Attribution Non-Commercial License (http://creativecommons.org/licenses/by-nc/3.0/) which permits unrestricted, non-commercial use, distribution and reproduction in any medium, provided the work is properly cited. 